Article

\title{
New 3-Hydroxyquinaldic Acid Derivatives from Cultures of the Marine Derived Actinomycete Streptomyces cyaneofuscatus M-157
}

\author{
Francisco Javier Ortiz-López ${ }^{1,+}$ (D) , Elsa Alcalde ${ }^{1,+}{ }^{+}$Aida Sarmiento-Vizcaíno ${ }^{2}$, Caridad Díaz ${ }^{1}$, \\ Bastien Cautain ${ }^{1}$, Luis A. García ${ }^{3}$, Gloria Blanco ${ }^{2, *}$ and Fernando Reyes ${ }^{1, *}$ (D) \\ 1 Fundación MEDINA, Centro de Excelencia en Investigación de Medicamentos Innovadores en Andalucía, \\ Avda. del Conocimiento 3, Parque Tecnológico de Ciencias de la Salud, E-18016 Granada, Spain; \\ javier.ortiz@medinaandalucia.es (F.J.O.-L.); elsaalcalde@uma.es (E.A.); \\ caridad.diaz@medinaandalucia.es (C.D.); bastien.cautain@medinaandalucia.es (B.C.) \\ 2 Departamento de Biología Funcional, Área de Microbiología, and Instituto Universitario de Oncología del \\ Principado de Asturias, Universidad de Oviedo, 33006 Oviedo, Spain; UO209983@uniovi.es \\ 3 Departamento de Ingeniería Química y Tecnología del Medio Ambiente, Área de Ingeniería Química, \\ Universidad de Oviedo, 33006 Oviedo, Spain; luisag@uniovi.es \\ * Correspondence: gbb@uniovi.es (G.B.); fernando.reyes@medinaandalucia.es (F.R.); \\ Tel.: +34-985-103-205 (G.B.); +34-958-993-965 (F.R.) \\ + These authors contributed equally to this work.
}

Received: 13 September 2018; Accepted: 4 October 2018; Published: 8 October 2018

\begin{abstract}
Fractionation of the bioactive extract of a culture of the marine derived actinomycete Streptomyces cyaneofuscatus M-157 led to the isolation of the known 3-hydroxyquinaldic acid (4), its amide (5) and three new derivatives (1-3) containing different amino acid residues. The structures of the new molecules (1-3), including their absolute configuration, were determined by the analysis of their ESI-TOF MS and one-dimensional (1D) and two-dimensional (2D) NMR spectra and advanced Marfey's analysis of their hydrolyzation products. Compound 3 spontaneously dimerized in solution to give the disulfide derivative 6 . Unfortunately, none of the new compounds isolated confirmed the antimicrobial activity found in the bacterial extract, perhaps indicating that such antibacterial activity might be due to presence in the extract at the trace level of larger bioactive 3-hydroxyquinaldic acid derivatives from which compounds $\mathbf{1 - 3}$ are biosynthetic precursors. Cytotoxicity tests confirmed the moderate and weak $\mathrm{IC}_{50}$ values of 15.6 and $51.5 \mu \mathrm{M}$ for compounds 5 and $\mathbf{1}$, respectively.
\end{abstract}

Keywords: 3-hydroxyquinaldic acid; Streptomyces cyaneofuscatus; deep-sea actinobacteria; Cantabrian Sea

\section{Introduction}

Marine actinomycetes continue to be the source of new natural products with interesting bioactive properties. Among them, depsipeptides containing quinaldic acid moieties in their structures, also called chromodepsipeptides, constitute an interesting structural class due to their relevant biological activities. These include antibiotics, such as the antibiotics UK-63,052, UK-63,598, and UK-65,662 [1], and their sulfoxide derivatives RK-1355A and B [2], luzopeptins A-C [3-5], quinaldopeptin [6] and sandramycin $[7,8]$, or potent cytotoxic agents, such as thiocoraline $[9,10]$ or the structurally related thiochondrilline C [11]. Most of these compounds act as DNA bisintercalators, and in the case of thiocoraline, the two 3-hydroxyquinaldic moieties present in the molecule seem to confer stability to the complex with DNA as part of its mode of action [12].

A recent survey of marine actinomycete strains that were isolated from deep-sea water and invertebrates (1500-4700 m depth) collected during a cruise expedition to the submarine Avilés 
Canyon, Cantabrian Sea (Biscay Bay, Northeast Atlantic), identified 18 strains having antibiotic properties against a panel of Gram positive and Gram negative bacteria, including clinical isolates [13]. New natural products with antibiotic and cytotoxic activities were recently uncovered in diverse Actinobacteria that were isolated from this canyon [14-16]. We report here the discovery of a family of new compounds from one of these strains, M-157, isolated from a solitary coral belonging to the order Scleractinia collected at $2000 \mathrm{~m}$ depth in this Canyon, identified as Streptomyces cyaneofuscatus by $16 \mathrm{~S}$ rDNA. LC-HRMS dereplication [17] of the antimicrobial ethyl acetate extract of this strain identified the presence of 3-hydroquinaldic acid together with some new structurally related natural products. Fractionation of this extract using reversed phase flash chromatography and HPLC yielded 3-hydroxyquinaldic acid, its amide and three new derivatives (1-3) containing different amino acids as the major components of this extract.

\section{Results}

\subsection{Taxonomy and Phylogenetic Analysis of the Strain M-157}

The 16S rDNA of strain M-157 was previously amplified by polymerase chain reaction (PCR) and sequenced [13]. After Basic Logic Alignment Search Tool (BLAST) sequence comparison, strain M-157 showed 100\% identity to S. cyaneofuscatus (Accession number NR_115383); thus, this strain was designated as S. cyaneofuscatus M-157 (EMBL Sequence number LN824210). The phylogenetic tree that was generated by neighbour-joining and maximum likelihood method based on $16 \mathrm{~S}$ rDNA sequence clearly revealed the evolutionary relationship of strain M-157 with a group of known Streptomyces species (Figure 1).

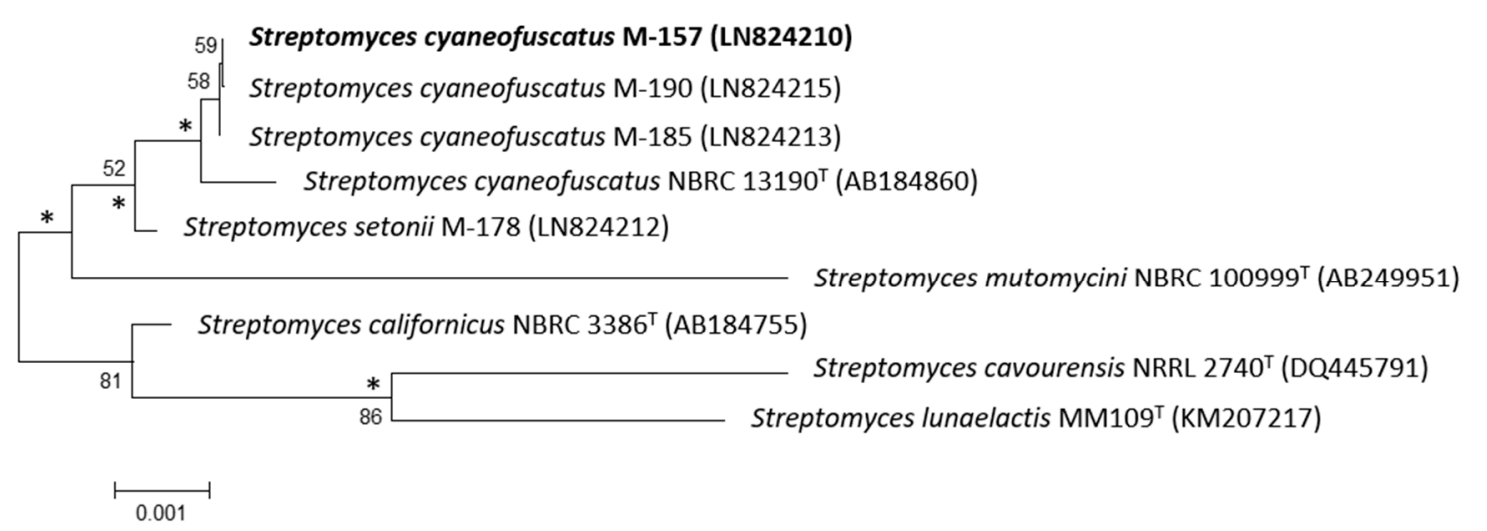

Figure 1. Neighbour-joining phylogenetic tree obtained by distance matrix analysis of $16 \mathrm{~S}$ rDNA sequences, showing Streptomyces cyaneofuscatus M-157 position and most closely related phylogenetic neighbours. Numbers on branch nodes are bootstrap values (1000 resamplings; only values $>50 \%$ are given). Asterisks indicate that the corresponding nodes were also recovered in the maximum likelihood tree. Bar indicates $0.1 \%$ sequence divergence.

\subsection{Isolation and Structural Elucidation of Compounds 1-3}

S. cyaneofuscatus M-157 was cultured in solid R5A medium and extracted with acidified ethyl acetate. This extract was fractionated using reversed phase C18 column chromatography followed by preparative HPLC to yield compounds 1-3, together with the known compounds 3-hydroxiquinaldic acid (4) and its amide (5) (Figure 2), which were identified by ESI-TOF MS and comparison of their NMR spectra with those that were described in the literature [18,19]. During the structural characterization of compound 3, a spontaneous dimerization through disulphide bond formation in DMSO- $d_{6}$ solution led to its full conversion into compound $\mathbf{6}$. 
<smiles>[R]C(=O)c1nc2ccccc2cc1O</smiles>

Figure 2. Compounds isolated from Streptomyces cyaneofuscatus M-157.

Compound 1, isolated as a yellow amorphous solid, possess a molecular formula of $\mathrm{C}_{13} \mathrm{H}_{12} \mathrm{~N}_{2} \mathrm{O}_{5}$, deduced from the presence of a protonated ion at $m / z 277.0821$ in its ESI-TOF mass spectrum and 13 signals in its ${ }^{13} \mathrm{C}$ NMR spectrum. Absorption maxima at 232, 308, and $360 \mathrm{~nm}$ in its UV spectrum and signals present in the aromatic region of its ${ }^{1} \mathrm{H}\left(\delta_{\mathrm{H}} 8.05 \mathrm{~d}, 7.91 \mathrm{dd}, 7.89 \mathrm{~s}, 7.66 \mathrm{~m}\right.$, and $\left.7.63 \mathrm{~m}\right)$ and ${ }^{13} \mathrm{C}$ NMR spectra $\left(\delta_{C} 153.1,140.8,134.6,131.6,129.0,128.9,127.8\right.$, and 126.7$)$, together with the conjugated carbonyl signal in the latter spectrum at $167.8 \mathrm{ppm}$ and a phenol group at $\delta_{\mathrm{H}} 12.01 \mathrm{ppm}$ confirmed the presence of a 3-hydroxyquinaldic moiety. The remaining signals observed in its ${ }^{1} \mathrm{H}$ and ${ }^{13} \mathrm{C}$ NMR spectra (Table 1) accounted for a nitrogenated methine $\left(\delta_{\mathrm{H}} 4.61 \mathrm{ddd}, \delta_{\mathrm{C}} 54.6\right)$, an oxygenated methylene $\left(\delta_{\mathrm{H}} 3.98 \mathrm{dd}\right.$ and $\left.3.89 \mathrm{dd}, \delta_{\mathrm{C}} 60.8\right)$, a carbonyl group $\left(\delta_{\mathrm{C}} 171.1\right)$, an amide $\mathrm{NH}$ group $\left(\delta_{\mathrm{H}} 9.19 \mathrm{~d}\right)$, and one hydroxy group $\left(\delta_{\mathrm{H}} 13.11 \mathrm{br}\right.$ s), the latter probably corresponding to a carboxylic acid functionality. COSY and HMBC correlations (Figure 3) assigned these signals to the presence of a serine residue that was linked to the 3-hydroxyquinaldic moiety through an amide bond between the amino group of the serine and the carbonyl group of 3-hydroxyquinaldic acid, as evidenced by HMBC correlations from the amide $\mathrm{NH}$ proton and $\mathrm{H}-1^{\prime}$ to the carbonyl carbon C-1. Advanced Marfey's analysis [20] established the absolute configuration of the serine residue as $\mathrm{L}$ after hydrolysis, derivatization with $N^{\alpha}$-(2,4-dinitro-5-fluorophenyl)-L-valinamide (L-FDVA) and LC/MS analysis.

The molecular formula of compound 2 was established as $\mathrm{C}_{15} \mathrm{H}_{15} \mathrm{~N}_{3} \mathrm{O}_{5}$, according to the protonated ion observed at $m / z 318.1088$ in its ESI-TOF spectrum. Signals with similar chemical shifts to those of 1 in the aromatic regions of its ${ }^{1} \mathrm{H}$ and ${ }^{13} \mathrm{C}$ NMR spectra and UV absorption maxima at 232, 308, and $360 \mathrm{~nm}$ accounted again for the presence of a 3-hydroxyquinaldic moiety. The remaining signals that were observed in its NMR spectra were assigned to one nitrogenated methine $\left(\delta_{\mathrm{H}} 4.53 \mathrm{ddd}, \delta_{\mathrm{C}} 52.3\right)$, two aliphatic methylenes $\left(\delta_{\mathrm{H}} 2.22 \mathrm{~m}(2 \mathrm{H}), \delta_{\mathrm{C}} 31.6\right.$, and $\delta_{\mathrm{H}} 2.22 \mathrm{~m}$ and $\left.2.11 \mathrm{~m}, \delta_{\mathrm{C}} 26.5\right)$, two carbonyl groups $\left(\delta_{\mathrm{C}} 173.8\right.$ and 172.7$)$, and amide $\mathrm{NH}\left(\delta_{\mathrm{H}} 9.53 \mathrm{~d}\right)$ and $\mathrm{NH}_{2}$ groups $\left(\delta_{\mathrm{H}} 7.32 \mathrm{br}\right.$ s and $\left.6.80 \mathrm{br} \mathrm{s}\right)$, which together with correlations observed in the COSY and HMBC spectra (Figure 4) indicated that they belonged to a glutamine (Gln) unit. The structure of compound 2 was finally established as the amide formed between the amino group of Gln and the carboxylate of 3-hydroxyquinaldic acid through the HMBC correlation observed between the amide $\mathrm{NH}$ proton and the carbonyl carbon $\mathrm{C}-1$ (Figure 4). Hydrolysis in $2 \mathrm{~N} \mathrm{HCl}$ followed by derivatization with $N^{\alpha}$-(2,4-dinitro-5-fluorophenyl)-L-valinamide (L-FDVA) and LC/MS analysis established the absolute configuration of the Gln residue present in $\mathbf{2}$ as L by comparison with glutamic acid standards. 
Table 1. NMR spectroscopic data (DMSO- $d_{6}, 500 \mathrm{MHz}$ ) for compounds $\mathbf{1}$ and 2.

\begin{tabular}{|c|c|c|c|c|}
\hline \multirow{2}{*}{ Position } & \multicolumn{2}{|r|}{1} & \multicolumn{2}{|r|}{2} \\
\hline & $\delta_{C}$, Type & $\delta_{H}(J$ in $\mathbf{H z})$ & $\delta_{C}$, Type * & $\delta_{H}(J$ in $\mathbf{H z})$ \\
\hline 1 & $167.8, \mathrm{C}$ & & $168.7, \mathrm{C}$ & \\
\hline 2 & $134.6, \mathrm{C}$ & & $135.4, \mathrm{C}$ & \\
\hline 3 & $153.1, \mathrm{C}$ & & $153.4, \mathrm{C}$ & \\
\hline 4 & $120.3, \mathrm{CH}$ & $7.89, \mathrm{~s}$ & $120.4, \mathrm{CH}$ & $7.87, \mathrm{~s}$ \\
\hline 5 & 131.6, $\mathrm{CH}$ & & $131.7, \mathrm{CH}$ & \\
\hline 6 & $126.7, \mathrm{CH}$ & $7.91, \mathrm{dd}(7.6,1.8)$ & 127.0, $\mathrm{CH}$ & $7.91, \mathrm{~d}(7.6,1.7)$ \\
\hline 7 & $128.9, \mathrm{CH}$ & $7.63, \mathrm{~m}$ & $129.2, \mathrm{CH}$ & $7.65, \mathrm{~m}$ \\
\hline 8 & $127.8, \mathrm{CH}$ & $7.66, \mathrm{~m}$ & $128.0, \mathrm{CH}$ & $7.67, \mathrm{~m}$ \\
\hline 9 & $129.0, \mathrm{CH}$ & $8.05, \mathrm{~d}(8.3)$ & $129.4, \mathrm{CH}$ & $8.05, \mathrm{~d}(8.0)$ \\
\hline 10 & $140.8, \mathrm{C}$ & & $141.2, \mathrm{C}$ & \\
\hline $3-\mathrm{OH}$ & & $12.01, \mathrm{~s}$ & & $12.05, \mathrm{~s}$ \\
\hline $1^{\prime}$ & $171.1, \mathrm{C}$ & & $172.7, \mathrm{C}$ & \\
\hline $2^{\prime}$ & $54.6, \mathrm{CH}$ & $4.61, \operatorname{ddd}(8.1,4.2,3.3)$ & $52.3, \mathrm{CH}$ & $4.53, \operatorname{ddd}(8.6,8.0,3.7)$ \\
\hline $3^{\prime}$ & $60.8, \mathrm{CH}_{2}$ & $\begin{array}{l}3.98, \mathrm{dd}(11.2,4.2) \\
3.89, \mathrm{dd}(11.2,3.3)\end{array}$ & $26.5, \mathrm{CH}_{2}$ & $\begin{array}{l}2.22, \mathrm{~m} \\
2.11, \mathrm{~m}\end{array}$ \\
\hline $\begin{array}{l}4^{\prime} \\
5^{\prime}\end{array}$ & - & - & $\begin{array}{l}31.6, \mathrm{CH}_{2} \\
173.8, \mathrm{C}\end{array}$ & $2.22, \mathrm{~m}, 2 \mathrm{H}$ \\
\hline $\mathrm{NH}$ & & $9.19, \mathrm{~d}(8.1)$ & & $9.53, \mathrm{~d}(8.8)$ \\
\hline $\mathrm{COOH}$ & & 13.11 , br s & & - \\
\hline $\mathrm{NH}_{2}$ & & - & & 7.32, br s $/ 6.80$, br s \\
\hline
\end{tabular}

${ }^{*}$ Chemical shifts determined using HSQC and HMBC experiments.

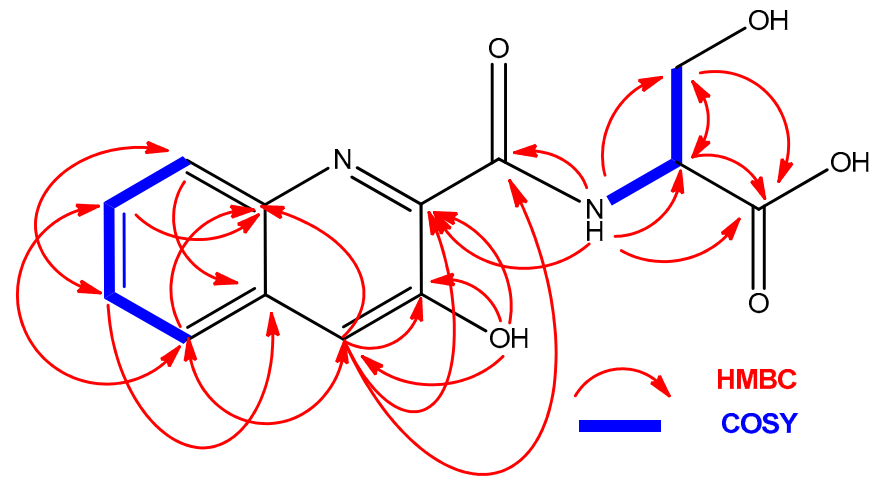

Figure 3. COSY and HMBC correlations observed in the structure of $\mathbf{1 .}$

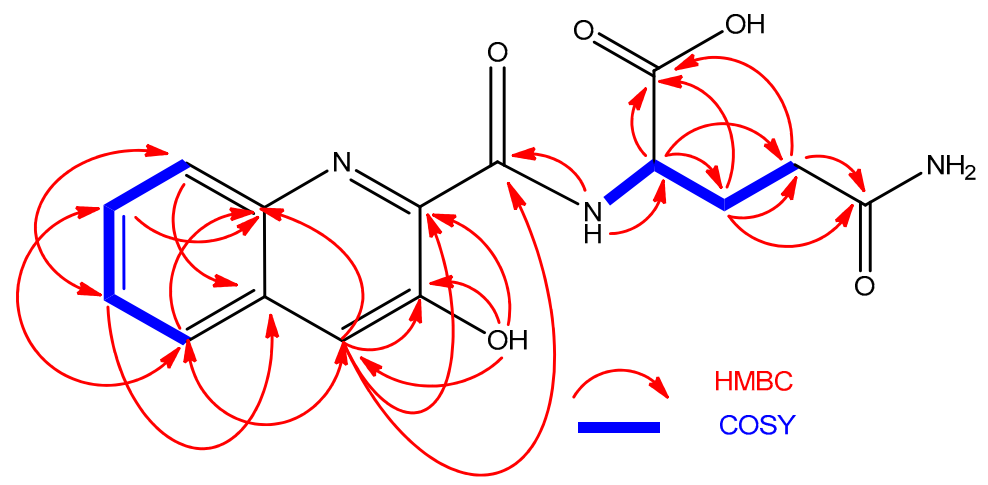

Figure 4. COSY and HMBC correlations observed in the structure of 2.

ESI-TOF analysis of compound 3 rendered a molecular formula of $\mathrm{C}_{16} \mathrm{H}_{13} \mathrm{~N}_{3} \mathrm{O}_{5} \mathrm{~S}$ according to the protonated ion at $\mathrm{m} / \mathrm{z} 360.0650$ observed in its spectrum. In addition to the presence of a 
3-hydroxiquinaldic acid moiety, evidenced by its UV spectrum and NMR signals with chemical shifts similar to those observed in $\mathbf{1}$ and 2, the NMR spectra of $\mathbf{3}$ (Table 2) displayed signals indicative of the presence of a 2-substituted oxazole-4-carboxylate $\left(\delta_{\mathrm{H}} 8.96 \mathrm{~s}, \delta_{\mathrm{C}} 159.2,159.1,143.6\right.$, and 136.2) and a cysteine residue $\left[\delta_{\mathrm{C}} 172.0(\mathrm{CO}) ; \delta_{\mathrm{H}} 5.58 \mathrm{~m}, \delta_{\mathrm{C}} 55.3(\mathrm{CH}) ; \delta_{\mathrm{H}} 3.08\right.$ and $2.96 \mathrm{~m}, \delta_{\mathrm{C}} 25.6\left(\mathrm{CH}_{2}\right)$; $\left.\delta_{\mathrm{H}} 9.20(\mathrm{NH})\right]$. Spontaneous conversion of 3 into its dimer 6 was observed in DMSO- $d_{6}$ solutions during 2D-NMR acquisition. After complete conversion, the presence of 6 was evidenced by changes in the cysteine ${ }^{1} \mathrm{H}$ and ${ }^{13} \mathrm{C}$ NMR chemical shifts (Table 2), particularly those of the methylene $\mathrm{C}-3^{\prime \prime}$ attached to the sulfur atom, whose ${ }^{13} \mathrm{C}$ signal was highly deshielded from 25.6 in 3 to $39.3 \mathrm{ppm}$ in 6 due to the formation of the disulfide bridge. COSY and HMBC correlations (Figure 5) that were observed in the spectra of 6 established the structures of both compounds, the monomer and the dimer, as depicted in Figure 2. This full conversion was confirmed by ESI-TOF analysis of the recovered sample, where a protonated ion observed at $m / z 717.1057$, accounting for a molecular formula of $\mathrm{C}_{32} \mathrm{H}_{25} \mathrm{~N}_{6} \mathrm{O}_{10} \mathrm{~S}_{2}$, was the unique component detected. This spontaneous dimerization was further monitored by time-course ${ }^{1} \mathrm{H}$ NMR experiments with a fresh sample of monomer 3 (see Figure S32). Finally, the absolute configuration of the cysteine residue in compound 3 (and therefore that of the dimeric compound 6) was determined to be L by Marfey's analysis of the corresponding cysteic acid derivative [21]. For this purpose, compound 3 was oxidized with performic acid and the resulting product was hydrolyzed, subsequently derivatized with L-FDVA and then analyzed by LCMS. Derivatization in parallel of a standard of L-cysteic acid derivatized with both, L and D-FDVA, provided the L-cysteic-L-FDVA and L-cysteic-D-FDVA (enantiomer of D-cysteic-L-FDVA) standards that are necessary to perform the Marfey's analysis.

Table 2. NMR spectroscopic data (DMSO- $d_{6}, 500 \mathrm{MHz}$ ) for compounds 3 and 6 .

\begin{tabular}{|c|c|c|c|c|}
\hline \multirow{2}{*}{ Position } & \multicolumn{2}{|c|}{3} & \multicolumn{2}{|r|}{6} \\
\hline & $\delta_{C}$, Type $*$ & $\delta_{\mathrm{H}}(J$ in $\mathrm{Hz})$ & $\delta_{C}$, Type * & $\delta_{H}(J$ in $\mathrm{Hz})$ \\
\hline 1 & $159.1, \mathrm{C}$ & & $159.1, \mathrm{C}$ & \\
\hline 2 & $134.5, \mathrm{C}$ & & 134.1, C & \\
\hline 3 & $150.2, \mathrm{C}$ & & $150.2, \mathrm{C}$ & \\
\hline 4 & $119.8, \mathrm{CH}$ & 7.96 , br s & $119.7, \mathrm{CH}$ & 7.92, br s \\
\hline 5 & $130.4, \mathrm{C}$ & & $130.4, \mathrm{C}$ & \\
\hline 6 & 127.0, $\mathrm{CH}$ & 7.89, dd $(7.4,1.8)$ & 127.0, $\mathrm{CH}$ & $7.89, \mathrm{dd}(7.1,1.6)$ \\
\hline 7 & $128.9, \mathrm{CH}$ & $7.59, \mathrm{~m}$ & $128.9, \mathrm{CH}$ & 7.59, ddd $(7.1,6.8,1.4)$ \\
\hline 8 & $128.0, \mathrm{CH}$ & $7.63, \mathrm{~m}$ & $128.0, \mathrm{CH}$ & 7.62, ddd $(8.1,6.8,1.6)$ \\
\hline 9 & $129.4, \mathrm{CH}$ & 8.03, br d $(7.8)$ & $129.4, \mathrm{CH}$ & 8.00, br d (8.1) \\
\hline 10 & $142.5, \mathrm{C}$ & & $142.4, \mathrm{C}$ & \\
\hline $3-\mathrm{OH}$ & & $10.61, \mathrm{~s}$ & & $10.45, \mathrm{~s}$ \\
\hline $1^{\prime}$ & 159.2, C & & $159.2, \mathrm{C}$ & \\
\hline $2^{\prime}$ & $136.2, \mathrm{C}$ & & 136.0, C & \\
\hline $3^{\prime}$ & $143.6, \mathrm{CH}$ & $8.96, \mathrm{~s}$ & $143.8, \mathrm{CH}$ & $8.90, \mathrm{~s}$ \\
\hline $1^{\prime \prime}$ & $172.0, \mathrm{C}$ & & $172.0, \mathrm{C}$ & \\
\hline $2^{\prime \prime}$ & $55.3, \mathrm{CH}$ & $4.58, \mathrm{~m}$ & $51.6, \mathrm{CH}$ & 4.79, ddd $(8.5,4.5,4.3)$ \\
\hline $3 "$ & $25.6, \mathrm{CH}_{2}$ & $\begin{array}{l}3.08, \mathrm{~m} \\
2.96, \mathrm{~m}\end{array}$ & $39.3, \mathrm{CH}_{2}$ & $\begin{array}{c}3.38, \mathrm{~m} \\
3.19, \mathrm{dd}(12.6,4.5)\end{array}$ \\
\hline $\mathrm{NH}$ & & & & $9.20, \mathrm{~d}(8.5)$ \\
\hline $\mathrm{COOH}$ & & & & 13.09, br s \\
\hline
\end{tabular}

${ }^{*}$ Chemical shifts determined using HSQC and HMBC experiments. 


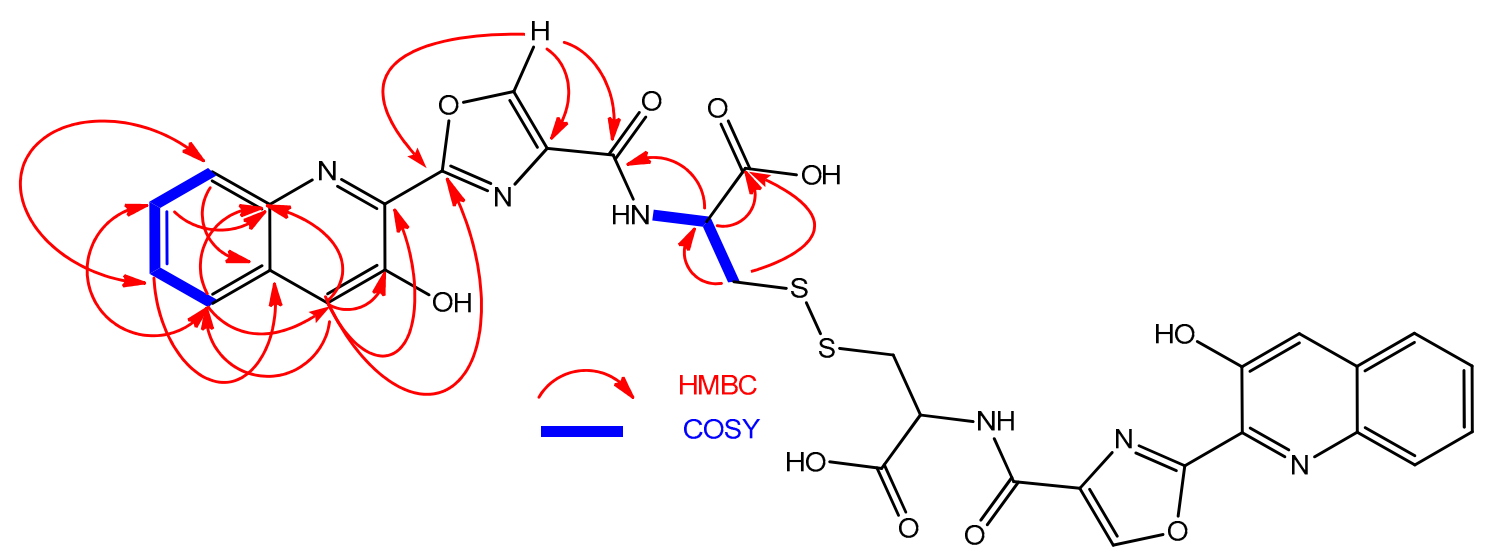

Figure 5. COSY and HMBC correlations observed in the structure of 6.

Compounds 1, 2 and 4-6 were tested against a small panel of pathogenic bacteria, including one Gram positive (methicillin resistant Staphylococcus aureus, MRSA) and two Gram negative (Escherichia coli and Acinetobacter baumannii) strains. None of the compounds displayed antimicrobial activity at the highest concentration tested of $64 \mu \mathrm{g} / \mathrm{mL}$. Additionally, cytotoxicity tests against the human tumor cell line HepG2 were also performed. Moderate and weak activities were observed for compounds 5 and 1, with $\mathrm{IC}_{50}$ values of 15.6 and $51.5 \mu \mathrm{M}$, respectively. No activity was observed for the rest of the compounds at the highest concentration tested $(20 \mu \mathrm{g} / \mathrm{mL})$.

\section{Discussion}

Three new 3-hydroxyquinaldic acid derivatives were isolated from the bioactive extract of $S$. cyaneofuscatus M-157. The structure of all the molecules isolated, including their absolute configurations, were fully established by HRMS, NMR, and Marfey's analysis. Compound $\mathbf{3}$ is most probably biosynthesized from the serine precursor 1 via elongation of the peptidic sequence with a cysteine residue and post-translational heterocyclization (cylodehydration and dehydrogenation) of the serine residue onto the carbonyl group of quinaldic acid to form an oxazole ring [22]. Most of the compounds isolated were tested against a set of pathogenic microorganisms, but none of them displayed the antimicrobial properties that are found in the crude extract. Additional tests against the human tumor cell line HepG2 were also performed, indicating moderate and weak activity for compounds $\mathbf{5}$ and $\mathbf{1}$, respectively. Other bioactive compounds with an elongated peptide chain might also be present in trace amounts in the extract. Interestingly, the three new compounds isolated possess structural features that are compatible with being biosynthetic precursors of larger chromodepsipeptides, similar to known antibacterial or cytotoxic agents, such as the luzopeptins, quinaldomycin, sandramycin, or thiochoraline, whose presence in low amounts in the extract would explain the antimicrobial properties that were observed.

To prove this hypothesis, experimental evidences of the production of such molecules should be obtained, perhaps using cultivation-based techniques (OSMAC approaches) to try to maximize the number of different molecules produced by our microbial strain and eventually trigger the production in higher amounts of the actual bioactive metabolites [23].

\section{Materials and Methods}

\subsection{General Experimental Procedures}

Optical rotations were measured using a Jasco P-2000 polarimeter (JASCO Corporation, Tokyo, Japan). UV spectra were obtained with an Agilent 1100 DAD (Agilent Technologies, Santa Clara, CA, USA). IR spectra were recorded on a JASCO FT/IR-4100 spectrometer (JASCO Corporation, Tokyo, Japan) equipped with a PIKE MIRacle ${ }^{\mathrm{TM}}$ single reflection ATR accessory (PIKE Thecnologies Inc., Madison, WI, USA). NMR spectra were recorded on a Bruker Avance III spectrometer (500 and 
$125 \mathrm{MHz}$ for ${ }^{1} \mathrm{H}$ and ${ }^{13} \mathrm{C}$ NMR, respectively) equipped with a $1.7 \mathrm{~mm}$ TCI MicroCryoProbe ${ }^{\mathrm{TM}}$ (Bruker Biospin, Falländen, Switzerland). Chemical shifts were reported in ppm while using the signals of the residual solvent as internal reference $\left(\delta_{\mathrm{H}} 2.50\right.$ and $\delta_{\mathrm{C}} 39.5$ for DMSO- $\left.d_{6}\right)$. LC-MS and LC-HRMS analyses were performed, as described previously [24].

\subsection{Taxonomic Identification of the Producing Microorganism}

Strain S. cyaneofuscatus M-157 was subjected to phylogenetic analysis based on $16 \mathrm{~S}$ rDNA sequence analysis [13]. Phylogenetic analysis was performed using MEGA version 6.0 [25] after multiple alignment of data by Clustal Omega [26]. Distances (distance options according to the Kimura two-parameter model [27]) and clustering with the neighbour-joining [28] and maximum likelihood [29] methods were evaluated using bootstrap values that were based on 1000 replications [30].

\subsection{Fermentation of the Producing Microorganism}

100 petri dishes with R5A solid medium [31] were inoculated with spores of strain M-157. After three weeks at $28{ }^{\circ} \mathrm{C}$, plates were extracted with ethyl acetate under acidic conditions $(1 \%$ formic acid). The extract was evaporated to dryness, resuspended in tert-butanol: water (1:1) and freeze dried.

\subsection{Extraction and Bioassay-Guided Isolation}

The whole biomass resulting from a 100 Petri dishes culture of strain M-157 was extracted with ethyl acetate under acidic conditions ( $1 \%$ formic acid). The extract was evaporated to dryness, resuspended in tert-butanol: water (1:1) and freeze dried. The lyophilized powder (ca. $600 \mathrm{mg}$ ) was disolved in DMSO and injected into a reversed phase column (Phenomenex Sepra ${ }^{\text {TM }}$ C18-E (Phenomenex, Inc., Torrance, CA, USA), $50 \mu \mathrm{m}, 65 \AA$, $70 \mathrm{~g}$ ). The column was eluted with a $\mathrm{H}_{2} \mathrm{O}$ : $\mathrm{CH}_{3} \mathrm{CN}$ linear gradient of decreasing polarity $(15 \mathrm{~mL} / \mathrm{min} ; 20-60 \%$ acetonitrile in $42 \mathrm{~min}$ with a final isocratic step of $100 \%$ acetonitrile for $15 \mathrm{~min}$ ), collecting 40 fractions of $15 \mathrm{~mL}$. Fractions were evaporated to dryness in a centrifugal evaporator and then analyzed by LC/MS to locate the target 3-hydroxyquinaldic derivatives based on their UV and mass spectra.

3-Hydroxy-quinaldic acid $(4,77.0 \mathrm{mg})$ was identified as the unique component of fractions $10-11$ by LC/MS and ${ }^{1} \mathrm{H}$ NMR analysis.

Fractions 16-19 were dissolved in DMSO and purified by reversed-phase preparative HPLC (Agilent Zorbax SB-C8 PrepHT, $21.2 \times 250 \mathrm{~mm}$ ) eluting with a linear gradient of $\mathrm{H}_{2} \mathrm{O}-0.1 \%$ TFA: $\mathrm{CH}_{3} \mathrm{CN}-0.1 \%$ TFA $\left(15 \mathrm{~mL} / \mathrm{min}, 20-32 \% \mathrm{CH}_{3} \mathrm{CN}\right.$ in $40 \mathrm{~min}$ ), to yield compound $\mathbf{1}\left(5.1 \mathrm{mg} ; t_{\mathrm{R}}: 24.0 \mathrm{~min}\right)$ and compound $2\left(2.2 \mathrm{mg}, t_{\mathrm{R}}: 20.4 \mathrm{~min}\right)$.

Fractions 28-31 were dissolved in DMSO and purified by reversed-phase preparative HPLC (Agilent Zorbax SB-C8 PrepHT, $21.2 \times 250 \mathrm{~mm}$ ) eluting with a linear gradient of $\mathrm{H}_{2} \mathrm{O}-0.1 \%$ TFA: $\mathrm{CH}_{3} \mathrm{CN}-0.1 \%$ TFA ( $15 \mathrm{~mL} / \mathrm{min}, 20-50 \% \mathrm{CH}_{3} \mathrm{CN}$ in $40 \mathrm{~min}$ ) to yield compound $3\left(1.7 \mathrm{mg} ; t_{\mathrm{R}}: 18.9 \mathrm{~min}\right)$ and the known compound 3-hydroxyquinoline-2-carboxamide (5, $\left.4.2 \mathrm{mg}, t_{\mathrm{R}}: 20.9 \mathrm{~min}\right)$.

During the structural characterization of compound 3, a spontaneous dimerization through a disulfide bond formation on standing on DMSO- $d_{6}$ led to full conversion into compound 6.

Compound 1: yellow solid; $[\alpha]_{\mathrm{D}}^{20}+42.9\left(\right.$ c 0.35, MeOH); UV (DAD) $\lambda_{\max } 232,308,360 \mathrm{~nm}$; IR (ATR) $v_{\max } 3341,2946,1660,1531,1187,1138,1018,797 \mathrm{~cm}^{-1}$; for ${ }^{1} \mathrm{H}$ and ${ }^{13} \mathrm{C}$ NMR data see Table 1; (+)-ESI-TOFMS $m / z 277.0821[\mathrm{M}+\mathrm{H}]^{+}$(calcd. for $\left.\mathrm{C}_{13} \mathrm{H}_{13} \mathrm{~N}_{2} \mathrm{O}_{5}, 277.0824\right)$.

Compound 2: yellow solid; $[\alpha]_{\mathrm{D}}^{20}-9.6$ (c 0.17, MeOH); UV (DAD) $\lambda_{\max } 232$, sh 308, $360 \mathrm{~nm}$; IR (ATR) $v_{\max } 3343,2946,1658,1532,1185,1135,1019,721 \mathrm{~cm}^{-1}$; for ${ }^{1} \mathrm{H}$ and ${ }^{13} \mathrm{C}$ NMR data see Table 1; (+)-ESI-TOFMS $m / z 318.1088$ [M + H] $]^{+}$(calcd. for $\mathrm{C}_{15} \mathrm{H}_{16} \mathrm{~N}_{3} \mathrm{O}_{5}, 318.1090$ ).

Compound 3: yellow solid; $[\alpha]_{\mathrm{D}}^{20}+3.3\left(c\right.$ 0.47, MeOH); UV (DAD) $\lambda_{\max } 230,260,308,360 \mathrm{~nm}$; IR (ATR) $v_{\max } 3371,2954,1672,1452,1195,1140,1019,845,800,724 \mathrm{~cm}^{-1}$; for ${ }^{1} \mathrm{H}$ and ${ }^{13} \mathrm{C}$ NMR data see Table 2; (+)-ESI-TOFMS $m / z 360.0650[\mathrm{M}+\mathrm{H}]^{+}$(calcd. for $\mathrm{C}_{16} \mathrm{H}_{14} \mathrm{~N}_{3} \mathrm{O}_{5} \mathrm{~S}, 360.0654$ ). 
Compound 6: yellow solid; $[\alpha]_{\mathrm{D}}^{20}-8.4$ (c 0.29, MeOH); UV (DAD) $\lambda_{\max } 230,260,308,360 \mathrm{~nm}$; IR (ATR) $v_{\max } 3238,2954,2927,1669,1515,1441,1203,1140,840,723 \mathrm{~cm}^{-1}$; for ${ }^{1} \mathrm{H}$ and ${ }^{13} \mathrm{C}$ NMR data see Table 2; (+)-ESI-TOFMS m/z 717.1063 [M + H] (calcd. for $\mathrm{C}_{32} \mathrm{H}_{25} \mathrm{~N}_{6} \mathrm{O}_{10} \mathrm{~S}_{2}, 717.1073$ ).

\subsection{Hydrolysis and Marfey's Analysis of Compounds $\mathbf{1}$ and $\mathbf{2}$}

Samples $(300 \mu \mathrm{g})$ of compounds 1 and 2 were separately dissolved in $0.6 \mathrm{~mL}$ of $6 \mathrm{~N} \mathrm{HCl}$ and heated at $110{ }^{\circ} \mathrm{C}$ for $16 \mathrm{~h}$ in a sealed vial. The crude hydrolysates were evaporated to dryness under a nitrogen stream and each residue was dissolved in $100 \mu \mathrm{L}$ of water. A 1\% (w/v) solution $(100 \mu \mathrm{L})$ of L-FDVA (Marfey's reagent, $N^{\alpha}$-(2,4-dinitro-5-fluorophenyl)-L-valinamide) in acetone was added to an aliquot $(50 \mu \mathrm{L})$ of a $50 \mathrm{mM}$ solution of each amino acid standard (serine and aspartic acid, D, L, or DL mixture) and to the aqueous solution of each compound hydrolysate. After addition of $20 \mu \mathrm{L}$ of $1 \mathrm{M} \mathrm{NaHCO}_{3}$ solution, each mixture was incubated for $60 \mathrm{~min}$ at $40^{\circ} \mathrm{C}$. The reactions were quenched by addition of $10 \mu \mathrm{L}$ of $1 \mathrm{~N} \mathrm{HCl}$ and the crude mixtures were diluted with $700 \mu \mathrm{L}$ of acetonitrile and analyzed by ESI LC/MS on an Agilent 1100 single Quadrupole LC/MS. Separations were carried out on an Agilent Zorbax SB-C8 column $(2.1 \times 30 \mathrm{~mm}, 5 \mu \mathrm{m})$, maintained at $40{ }^{\circ} \mathrm{C}$. A mixture of two solvents, $\mathrm{A}\left(10 \% \mathrm{CH}_{3} \mathrm{CN}, 90 \% \mathrm{H}_{2} \mathrm{O}\right)$ and $\mathrm{B}\left(90 \% \mathrm{CH}_{3} \mathrm{CN}, 10 \% \mathrm{H}_{2} \mathrm{O}\right)$, both containing $1.3 \mathrm{mM}$ trifluoroacetic acid and $1.3 \mathrm{mM}$ ammonium formate, was used as the mobile phase under a linear gradient $(10-50 \%$ B in $6 \mathrm{~min}$ ) at a flow rate of $0.3 \mathrm{~mL} / \mathrm{min}$. Retention times ( $\mathrm{min}$ ) for the derivatized (L-FDVA) amino acid standards under these chromatographic conditions were as follows: L-Ser: 3.02; D-Ser: 3.42; L-Glu: 3.33 D-Glu: 3.83. Retention times $(\mathrm{min})$ for the observed peaks in the HPLC trace of the L-FDVA-derivatized hydrolysis products of compounds $\mathbf{1}$ and $\mathbf{2}$, in agreement with the presence of L-Ser (3.01) in $\mathbf{1}$ and L-Glu (3.37) in $\mathbf{2}$.

\subsection{Oxidation of Compound $\mathbf{3}$ with Performic Acid and Marfey's Analysis}

Compound $3(0.2 \mathrm{mg})$ was treated with $\mathrm{H}_{2} \mathrm{O}_{2}-\mathrm{HCOOH}(1: 4)(0.8 \mathrm{~mL})$ at $0{ }^{\circ} \mathrm{C}$ and the reaction mixture was allowed to reach room temperature over $2 \mathrm{~h}$. The oxidation of 3 to the corresponding cysteic acid derivative was confirmed by LC-HRMS (Figures S35 and S36). Solvents were evaporated to dryness under a $\mathrm{N}_{2}$ stream and the residue was hydrolyzed with $0.6 \mathrm{~mL}$ of $\mathrm{HCl} 6 \mathrm{~N}$ at $110{ }^{\circ} \mathrm{C}$ for $18 \mathrm{~h}$. The hydrolyzed product and the standard amino acid L-cysteic were separately derivatized with L-FDVA or D-FDVA under an analogous procedure to that used for Marfey's analysis of compounds 1 and 2. Separations were carried out on a Water Atlantis T3 C18 column $(4.6 \times 100 \mathrm{~mm}, 5 \mu \mathrm{m})$ maintained at $40{ }^{\circ} \mathrm{C}$. A mixture of water (A) and acetonitrile (B), both containing $0.1 \% \mathrm{HCOOH}$, was used as the mobile phase under a linear gradient $(25-30 \% \mathrm{~B}$ in $14 \mathrm{~min}$; then, $100 \% \mathrm{~B}$ ) at a flow rate of $1.0 \mathrm{~mL} / \mathrm{min}$. Retention times ( $\mathrm{min}$ ) for the derivatized (L-FDVA or D-FDVA) amino acid standard L-cysteic acid under these chromatographic conditions were as follows: L-cysteic: 9.38; D-cysteic (enantiomer of L-cysteic-D-FDVA): 8.51. Retention time $(9.56 \mathrm{~min}$ ) for the peak observed in the HPLC trace of the L-FDVA-derivatized hydrolysis of the oxidation product of compound $\mathbf{3}$ was in agreement with the presence of L-cysteic acid, and therefore with the presence of L-cysteine in compounds 3 and 6.

\subsection{Antibacterial Activity Assays}

The antibacterial activities of the compounds were evaluated using sequential 2-fold serial dilutions of each compound in DMSO to provide 10 concentrations starting at $64 \mu \mathrm{g} / \mathrm{mL}$ for all of the assays. Activity was measured against one Gram-positive (methicillin-resistant S. aureus MB5393) and two Gram-negative (E. coli MB2884 and A. baumannii MB5973) bacterial strains, as previously reported [32]. 


\subsection{Cytotoxicity Assays}

Cytotoxic activity against the HepG2 human tumor cell line was tested as previously described [33], using sequential 2-fold serial dilutions of each compound in DMSO to provide 10 concentrations starting at $20 \mu \mathrm{g} / \mathrm{mL}$.

Supplementary Materials: The following are available online at http://www.mdpi.com/1660-3397/16/10/ 371/s1, Figure S1: UV spectrum of compound 1; Figure S2: ESI-TOF spectrum of compound 1; Figure S3: ${ }^{1} \mathrm{H}$ NMR spectrum (DMSO- $d_{6}, 500 \mathrm{MHz}$ ) of compound 1; Figure S4: ${ }^{13} \mathrm{C}$ NMR spectrum (DMSO- $d_{6}, 125 \mathrm{MHz}$ ) of compound 1; Figure S5: COSY spectrum of compound 1; Figure S6: HSQC spectrum of compound 1; Figure S7: HMBC spectrum of compound 1; Figure S8: UV spectrum of compound 2; Figure S9: ESI-TOF spectrum of compound 2; Figure S10: ${ }^{1} \mathrm{H}$ NMR spectrum (DMSO- $d_{6}, 500 \mathrm{MHz}$ ) of compound 2; Figure S11: COSY spectrum of compound 2; Figure S12: HSQC spectrum of compound 2; Figure S13: HMBC spectrum of compound 2; Figure S14: UV spectrum of compound 3; Figure S15: ESI-TOF spectrum of compound 3; Figure S16: ${ }^{1} \mathrm{H}$ NMR spectrum (DMSO- $d_{6}, 500 \mathrm{MHz}$ ) of compound 3; Figure S17: COSY spectrum of compound 3; Figure S18: HSQC spectrum of compound 3; Figure S19: HMBC spectrum of compound 3; Figure S20: UV spectrum of compound 4; Figure S21: ESI-TOF spectrum of known compound 4; Figure S22: ${ }^{1} \mathrm{H}$ NMR spectrum $\left(\mathrm{CDCl}_{3}, 500 \mathrm{MHz}\right)$ of known compound 4; Figure S23: UV spectrum of compound 5; Figure S24: ESI-TOF spectrum of known compound 5; Figure S25: ${ }^{1} \mathrm{H}$ NMR spectrum (DMSO- $d_{6}, 500 \mathrm{MHz}$ ) of known compound 5; Figure S26: UV spectrum of compound 6; Figure S27: ESI-TOF spectrum of compound 6; Figure S28: ${ }^{1} \mathrm{H}$ NMR spectrum (DMSO- $d_{6}, 500 \mathrm{MHz}$ ) of compound 6; Figure S29: COSY spectrum of compound 6; Figure S30: HSQC spectrum of compound 6; Figure S31: HMBC spectrum of compound 6; Figure S32: ${ }^{1} \mathrm{H}-\mathrm{NMR}$ (DMSO- $d_{6}, 500 \mathrm{MHz}$ ) time-course conversion of 3 into 6; Figure S33: HPLC traces of Marfey's analysis of compound 1; Figure S34: HPLC traces of Marfey's analysis of compound 2; Figure S35: LC-HRMS analysis of the oxidation crude of compound 3; Figure S36: HRMS-MS spectrum of the oxidation product of compound 3; Figure S37: HPLC traces of L- and D-FDVA derivatives of standard L-cysteic acid; Figure S38: HPLC traces of Marfey's analysis of the oxidation product of compound 3.

Author Contributions: A.S.-V. and G.B. carried out the fermentation, extraction and taxonomic identification of the strain. E.A. performed the purification of the compounds. E.A., F.J.O.-L. and F.R. performed the structural elucidation of the compounds; C.D. performed the antibacterial assays; B.C. performed the cytotoxicity tests; L.A.G, G.B., F.J.O.-L. and F.R. conceived and supervised the work; F.R. and G.B. wrote the paper, which was revised and approved by all the authors.

Funding: This study was financially supported by the Universidad de Oviedo (UNOV-11-MA-02), Gobierno del Principado de Asturias (SV-PA-13-ECOEMP-62) and Fundación MEDINA. The polarimeter, IR, and NMR equipment used in this work were acquired via grants for scientific and technological infrastructures from the Ministerio de Ciencia e Innovación (Grants No. PCT-010000-2010-4 (NMR), INP-2011-0016-PCT-010000 ACT6 (polarimeter and IR)).

Acknowledgments: The authors are grateful to José Luis Acuña for his invitation to the BIOCANT3 oceanographic expedition (DOSMARES) where the strain M-157 of Streptomyces cyaneofuscatus was isolated. Jesús Martín, Ignacio Pérez-Victoria and Mercedes de la Cruz helped with the ESI-TOF, NMR analyses, and antibacterial assays, respectively. This is a contribution of the Asturias Marine Observatory.

Conflicts of Interest: The authors declare no conflict of interest.

\section{References}

1. Range, M.J.; Ruddock, J.C.; Pacey, M.S.; Cullen, W.P.; Huang, L.H.; Jefferson, M.T.; Whipple, E.B.; Maeda, H.; Tone, J. UK-63,052 complex, new quinomycin antibiotics from Streptomyces braegensis subsp. japonicus; Taxonomy, fermentation, isolation, characterisation and antimicrobial activity. J. Antibiot. 1989, 42, $206-217$. [CrossRef]

2. Lim, C.L.; Nogawa, T.; Uramoto, M.; Okano, A.; Hongo, Y.; Nakamura, T.; Koshino, H.; Takahashi, S.; Ibrahim, D.; Osada, H. RK-1355A and B, novel quinomycin derivatives isolated from a microbial metabolites fraction library based on NPPlot screening. J. Antibiot. 2014, 67, 323-329. [CrossRef] [PubMed]

3. Ohkuma, H.; Sakai, F.; Nishiyama, Y.; Ohbayashi, M.; Imanishi, H.; Konishi, M.; Miyaki, T.; Koshiyama, H.; Kawaguchi, H. BBM-928, a new antitumor antibiotic complex I. Production, isolation, characterization and antitumor activity. J. Antibiot. 1980, 33, 1087-1097. [CrossRef] [PubMed]

4. Tomita, K.; Hoshino, Y.; Sasahira, T.; Kawaguchi, H. BBM-928, a new antitumor antibiotic complex II. Taxonomic studies on the producing organism. J. Antibiot. 1980, 33, 1098-1102. [CrossRef] [PubMed] 
5. Konishi, M.; Ohkuma, H.; Sakai, F.; Tsuno, T.; Koshiyama, H.; Naito, T.; Kawaguchi, H. BBM-928, a new antitumor antibiotic complex. III. Structure determination of BBM-928 A, B and C. J. Antibiot. 1981, 34, 148-159. [CrossRef] [PubMed]

6. Toda, S.; Sugawara, K.; Nlshiyama, Y.; Ohbayashi, M.; Ohkusa, N.; Yamamoto, H.; Konishi, M.; Oki, T. Quinaldopeptin, a novel antibiotic of the quinomycin family. J. Antibiot. 1990, 43, 796-808. [CrossRef] [PubMed]

7. Matson, J.A.; Bush, J.A. Sandramycin, a novel antitumor antibiotic produced by a Nocardioides sp. Production, isolation, characterization and biological properties. J. Antibiot. 1989, 42, 1763-1767. [CrossRef] [PubMed]

8. Matson, J.A.; Colson, K.L.; Belofsky, G.N.; Bleiberg, B.B. Sandramycin, a novel antitumor antibiotic produced by a Nocardioides sp. II. Structure determination. J. Antibiot. 1993, 46, 162-166. [CrossRef] [PubMed]

9. Romero, F.; Espliego, F.; Pérez Baz, J.; García de Quesada, T.; Grávalos, D.; de la Calle, F.; Fernández-Puentes, J.L. Thiocoraline, a New Depsipeptide with Antitumor Activity Produced by a Marine Micromonospora. I. Taxonomy, Fermentation, Isolation, and Biological Activities. J. Antibiot. 1997, 50, 734-737. [CrossRef] [PubMed]

10. Pérez Baz, J.; Cañedo, L.M.; Fernández Puentes, J.L.; Silva Elipe, M.V. Thiocoraline, a Novel Depsipeptide with Antitumor Activity Produced by a Marine Micromonospora. II. Physico-chemical Properties and Structure Determination. J. Antibiot. 1997, 50, 738-741. [CrossRef] [PubMed]

11. Wyche, T.P.; Hou, Y.; Braun, D.; Cohen, H.C.; Xiong, M.P.; Bugni, T.S. First Natural Analogs of the Cytotoxic Thiodepsipeptide Thiocoraline A from a Marine Verrucosispora sp. J. Org. Chem. 2011, 76, 6542-6547. [CrossRef] [PubMed]

12. Negri, A.; Marco, E.; García-Hernández, V.; Domingo, A.; Llamas-Saiz, A.L.; Porto-Sandá, S.; Riguera, R.; Laine, W.; David-Cordonnier, M.-H.; Bailly, C.; et al. Antitumor Activity, X-ray Crystal Structure, and DNA Binding Properties of Thiocoraline A, a Natural Bisintercalating Thiodepsipeptide. J. Med. Chem. 2007, 50, 3322-3333. [CrossRef] [PubMed]

13. Sarmiento-Vizcaíno, A.; González, V.; Braña, A.F.; Palacios, J.J.; Otero, L.; Fernández, J.; Molina, A.; Kulik, A.; Vázquez, F.; Acuña, J.L.; et al. Pharmacological Potential of Phylogenetically Diverse Actinobacteria Isolated from Deep-Sea Coral Ecosystems of the Submarine Avilés Canyon in the Cantabrian Sea. Microb. Ecol. 2017, 73, 338-352. [CrossRef] [PubMed]

14. Braña, A.; Sarmiento-Vizcaíno, A.; Osset, M.; Pérez-Victoria, I.; Martín, J.; de Pedro, N.; de la Cruz, M.; Díaz, C.; Vicente, F.; Reyes, F.; et al. Lobophorin K, a New Natural Product with Cytotoxic Activity Produced by Streptomyces sp. M-207 Associated with the Deep-Sea Coral Lophelia pertusa. Mar. Drugs 2017, 15, 144. [CrossRef] [PubMed]

15. Braña, A.F.; Sarmiento-Vizcaíno, A.; Pérez-Victoria, I.; Otero, L.; Fernández, J.; Palacios, J.J.; Martín, J.; de la Cruz, M.; Díaz, C.; Vicente, F.; et al. Branimycins B and C, Antibiotics Produced by the Abyssal Actinobacterium Pseudonocardia carboxydivorans M-227. J. Nat. Prod. 2017, 80, 569-573. [CrossRef] [PubMed]

16. Sarmiento-Vizcaíno, A.; Braña, A.; Pérez-Victoria, I.; Martín, J.; de Pedro, N.; Cruz, M.; Díaz, C.; Vicente, F.; Acuña, J.; Reyes, F.; et al. Paulomycin G, a New Natural Product with Cytotoxic Activity against Tumor Cell Lines Produced by Deep-Sea Sediment Derived Micromonospora matsumotoense M-412 from the Avilés Canyon in the Cantabrian Sea. Mar. Drugs 2017, 15, 271. [CrossRef] [PubMed]

17. Pérez-Victoria, I.; Martín, J.; Reyes, F. Combined LC/UV/MS and NMR Strategies for the Dereplication of Marine Natural Products. Planta Med 2016, 82, 857-871. [CrossRef] [PubMed]

18. Riego, E.; Bayó, N.; Cuevas, C.; Albericio, F.; Álvarez, M. A new approach to 3-hydroxyquinoline-2-carboxylic acid. Tetrahedron 2005, 61, 1407-1411. [CrossRef]

19. Shaaban, K.A.; Shepherd, M.D.; Ahmed, T.A.; Nybo, S.E.; Leggas, M.; Rohr, J. Pyramidamycins A-D and 3-hydroxyquinoline-2-carboxamide; cytotoxic benzamides from Streptomyces sp. DGC1. J. Antibiot. 2012, 65, 615-622. [CrossRef] [PubMed]

20. Fujii, K.; Ikai, Y.; Oka, H.; Suzuki, M.; Harada, K.-I. A Nonempirical Method Using LC/MS for Determination of the Absolute Configuration of Constituent Amino Acids in a Peptide: Combination of Marfey's Method with Mass Spectrometry and Its Practical Application. Anal. Chem. 1997, 69, 5146-5151. [CrossRef]

21. Varga-Visi, E.; Terlaky-Balla, E.; Pohn, G.; Kamether, L.; Csapó, J. RPHPLC determination of L- and D-cystine and cysteine as cysteic acid. Chromatographia 2000, 51, S325-S327. [CrossRef] 
22. Walsh, C.T.; Malcolmson, S.J.; Young, T.S. Three Ring Posttranslational Circuses: Insertion of Oxazoles, Thiazoles, and Pyridines into Protein-Derived Frameworks. ACS Chem. Biol. 2012, 7, 429-442. [CrossRef] [PubMed]

23. Romano, S.; Jackson, S.A.; Patry, S.; Dobson, A.D.W. Extending the “One Strain Many Compounds” (OSMAC) Principle to Marine Microorganisms. Mar. Drugs 2018, 16, 244. [CrossRef] [PubMed]

24. Martín, J.; Crespo, G.; González-Menéndez, V.; Pérez-Moreno, G.; Sánchez-Carrasco, P.; Pérez-Victoria, I.; Ruiz-Pérez, L.M.; González-Pacanowska, D.; Vicente, F.; Genilloud, O.; et al. MDN-0104, an Antiplasmodial Betaine Lipid from Heterospora chenopodii. J. Nat. Prod. 2014, 77, 2118-2123. [CrossRef] [PubMed]

25. Tamura, K.; Stecher, G.; Peterson, D.; Filipski, A.; Kumar, S. MEGA6: Molecular Evolutionary Genetics Analysis Version 6.0. Mol. Biol. Evol. 2013, 30, 2725-2729. [CrossRef] [PubMed]

26. Sievers, F.; Wilm, A.; Dineen, D.; Gibson, T.J.; Karplus, K.; Li, W.; Lopez, R.; McWilliam, H.; Remmert, M.; Söding, J.; et al. Fast, scalable generation of high-quality protein multiple sequence alignments using Clustal Omega. Mol. Syst. Biol. 2011, 7, 539. [CrossRef] [PubMed]

27. Kimura, M. A simple method for estimating evolutionary rates of base substitutions through comparative studies of nucleotide sequences. J. Mol. Evol. 1980, 16, 111-120. [CrossRef] [PubMed]

28. Saitou, N.; Nei, M. The neighbor-joining method: A new method for reconstructing phylogenetic trees. Mol. Biol. Evol. 1987, 4, 406-425. [CrossRef] [PubMed]

29. Felsenstein, J. Evolutionary trees from DNA sequences: A maximum likelihood approach. J. Mol. Evol. 1981, 17, 368-376. [CrossRef] [PubMed]

30. Felsenstein, J. Confidence limits on phylogenies: An approach using the bootstrap. Evolution 1985, 39, 783-791. [CrossRef] [PubMed]

31. Fernández, E.; Weissbach, U.; Reillo, C.S.; Braña, A.F.; Méndez, C.; Rohr, J.; Salas, J.A. Identification of two genes from Streptomyces argillaceus encoding two glycosyltransferases involved in the transfer of a disaccharide during the biosynthesis of the antitrumor drug mithramycin. J. Bacteriol. 1998, 180, 4929-4937. [PubMed]

32. Audoin, C.; Bonhomme, D.; Ivanisevic, J.; Cruz, M.; Cautain, B.; Monteiro, M.; Reyes, F.; Rios, L.; Perez, T.; Thomas, O. Balibalosides, an Original Family of Glucosylated Sesterterpenes Produced by the Mediterranean Sponge Oscarella balibaloi. Mar. Drugs 2013, 11, 1477-1489. [CrossRef] [PubMed]

33. Cautain, B.; de Pedro, N.; Schulz, C.; Pascual, J.; da S Sousa, T.; Martin, J.; Pérez-Victoria, I.; Asensio, F.; González, I.; Bills, G.F.; et al. Identification of the Lipodepsipeptide MDN-0066, a Novel Inhibitor of VHL/HIF Pathway Produced by a New Pseudomonas Species. PLoS ONE 2015, 10, e0125221. [CrossRef] [PubMed]

(C) 2018 by the authors. Licensee MDPI, Basel, Switzerland. This article is an open access article distributed under the terms and conditions of the Creative Commons Attribution (CC BY) license (http:/ / creativecommons.org/licenses/by/4.0/). 